ORL 1993;55:245-248

\title{
Contents, Vol. 55, No.5, 1993
}

Verwoerd, C.D.A.

Introduction

Ultrasound for Diagnosis of Head and Neck Lesions

249

Baatenburg de Jong, R.J.; Rongen, R.J.

Ultrasound of the Head and Neck

250

Eichhorn, T.; Schroeder, H.G.

Ultrasound in Metastatic Neck Disease

258

Gooding, G.A.W .

Malignant Carotid Invasion: Sonographic Diagnosis

263

Baatenburg de Jong, R.J.; Knegt, P.; Verwoerd, C.D.A.

Assessment of Cervical Metastatic Disease

273

Laméris, J.S.

Color Flow Imaging of the Head and Neck Region

281

Bruneton, J.N.; Mourou, M.Y.

Ultrasound in Salivary Gland Disease

284

Baatenburg de Jong, R.J.; Rongen, R.J.; Laméris, J.S.; Knegt, P.; Verwoerd, C.D.A.

Ultrasound in the Diagnosis of Laryngoceles

290

Baatenburg de Jong, R.J.; Rongen, R.J.; Laméris, J.S.; Knegt, P.; Verwoerd, C.D.A.

Evaluation of Branchiogenic Cysts by Ultrasound

294

Baatenburg de Jong, R.J.; Rongen, R.J.; Laméris, J.S.; Knegt, P.; Verwoerd, C.D.A.

Ultrasound Characteristics of Thyroglossal Duct Anomalies

299

Mclvor, N.P.; Freeman, J.L.; Salem, S.

Ultrasonography of the Thyroid and Parathyroid Glands

303

Baatenburg de Jong, R.J.; Rongen, R.J. Guidelines for the Use of Ultrasound in the Head and Neck 309 